\title{
Effect of Azotobacter sp. and N Fertilizer on the Growth of Oil Palm Seedling Inoculated with Ganoderma sp.
}

\author{
Happy Widiastuti \\ Indonesian Research Institute for Biotechnology and Bioindustry, Bogor 16151, Indonesia
}

\begin{abstract}
Excess application of nitrogen fertilizer causes soil nutrient imbalances and reduce the number and soil microbial diversity. This condition could induce soil born dieseses such basal stem rot caused by Ganoderma sp. A study was conducted to enhance the plant tolerance to Ganoderma sp. through introduction of microbial community especially non-symbiotic N fixing bacteria, Azotobacter sp. Plant materials used were 4 months old of germinated oil palms, while Ganoderma sp. was isolated from Bekri, Lampung. There are seven treatments tested i e Azotobacter sp. + Ganoderma sp. (+A+G), Azotobacter sp. $+30 \% \mathrm{~N}$ fertilizer of recommended dosage + Ganoderma sp. $(+A+30 N+G)$, Azotobacter sp. $+60 \% \mathrm{~N}$ fertilizer of recommended dosage + Ganoderma sp. $(+\mathrm{A}+60 \mathrm{~N}+\mathrm{G})$, Azotobacter sp. $+100 \% \mathrm{~N}$ fertilizer of recommended dosage + Ganoderma sp. $(+A+100 N+G), 100 \% \mathrm{~N}$ fertilizer of recommended dosage + Ganoderma sp. $(+100 N+G)$, Ganoderma sp. inoculation (positive control, $+G$ ), and non-inoculated Ganoderma sp. (negative control, -G). The result showed that Azotobacter sp. enhanced the height of plant inoculated with Ganoderma sp. when accompanied with $\mathrm{N}$ fertilizer of 30 to $100 \%$ of recommended dose. Moreover, $+A+100 N+G$ seedling had significantly higher fresh and dry weight of shoot compared to those of $+G$ seedling or $+100 N+G$ seedling.
\end{abstract}

Key words: Elaeis guineensis, microbial community, oil, soil-born diseases, soil nutrient

\section{INTRODUCTION}

Nitrogen is the highest amount of nutrients added as fertilizer in soil compared to other macro nutrients such as $P$ and $\mathrm{K}$. Long term and high dose of $\mathrm{N}$ fertilizers, especially in the form as urea, is believed to change the soil nutrient balance and soil characteristics. The development of nutrient imbalances could cause various problems including decrease in soil

Corresponding author:

Indonesian Research Institute for Biotechnology and Bioindustry

Jalan Taman Kencana, Bogor 16151, Indonesia

E-mail: happywidiastuti@yahoo.com bearing capacity against soil pathogens. This resulted in decline of population of microbial antagonists that play a role in the control of soil borne pathogens. In general, $\mathrm{N}$ fertilization promotes vegetative growth, lowering the concentration of carbon-based secondary compounds (phenol, terpenoids) and increasing $\mathrm{N}$ compounds such as alkaloids (Rasmussen et al. 2008). In addition, excess of nitrogen input could decrease the defense of plants. Nitrogen enrichment can 
increase growth, and differently affect the shoot and root defense (Rasmussen et al. 2008; Jamieson et al. 2012). Excessive N fertilization can lead to $40 \%$ endophytic depletion and can increase the attack of certain plant diseases. Olese et al. (2003) suggests that increased $\mathrm{N}$ fertilizers may increase the attack of powdery mildew on wheat crops. However, excessive $\mathrm{N}$ fertilization impacting plant disease attacks and also has an impact on environmental pollution.

Azotobacter sp. is known as non-symbiotic N-fixing bacteria, Gram negative, obligate aerobic, and soil dwelling. Its role in $\mathrm{N}$ fixation is extensively researched because it can associate with various plant species. Besides known as $\mathrm{N}$ fixers, this bacterium is also known as a producer of IAA hormone which can enhance the growth of plant roots. Romero et al. (2013) suggests that this bacterium can survive in dry conditions because of its ability to form cysts that are controlled by the sigma factor RpoS. In addition, it is expected that application of Azotobacter improve the quality of oil as has been done on the plant Brassica carinata cv. Peela Raya. Addition of Azospirillum and Azotobacter in combination with a half-dose of chemical fertilizers enhance the growth, yield and quality of Ethiopian mustard oil (Nosheen et al. 2013).

In oil palm plantations at this time, there is a very important disease known as basal stem rot caused by Ganoderma sp. Widiastuti et al. (2013) reported that there was a decline in microbial diversity, especially in area with severe attack of Ganoderma sp. However, in all samples taken from selected area, Azotobacter sp. Were consistently found. Azotobacter associations with plants are thought to alter the nutrient status of $\mathrm{N}$ crops as well as exudation of plant roots in both the number and components of exudates which may further alter the rhizosphere microbial community (Lakshmanan et al. 2014). This change can be through changes in the physical properties of soil chemistry and or indirectly affect the microbial community of antagonists (Kloepper et al. 2004). Research on the characterization of Azotobacter sp. of various habitats have been carried out including estate crops (Widiastuti et al. 2010). This study aims to determine the effect of microbial community improvement through inoculation of Azotobacter bacteria on the growth performance of oil palm inoculated with Ganoderma sp.

\section{MATERIAL AND METHODS}

The experiment was conducted in Microbiology Laboratory and Greenhouse of Indonesian Research Institute for Biotechnology and Bioindustry (IRIBB). Planting materials used were germinated oil palm seeds from Indonesian Oil Palm Research Institute (IOPRI), Medan, grown for 4 months in sterilized sand medium, before they were transplanted in sterilized soil medium obtained from $\mathrm{Ci}$ omas, Bogor. Sterilization was done by autoclave for 60 minutes at $121{ }^{\circ} \mathrm{C}$ and pressure $1.2 \mathrm{~atm}$. Planting medium was filled in polybags $30 \times 40 \mathrm{~cm}^{2}$ in size. $\mathrm{N}$ fertilizer was given in the form of urea with a dose of $5 \mathrm{~g}$ referred as $100 \%$ standard. Ganoderma sp. was inoculated following the method of Widiastuti et al. (2011) prior to inoculation of Azotobacter sp. Inoculant of Azotobacter sp. with the concentration of $10^{8}$ colony forming units (cfu) in $10 \mathrm{~mL}$ water for each seedlings, applied at the beginning of planting the seeds, while the application of $\mathrm{N}$ fertilizer had been adjusted to the standard time of fertilization that is every 2 weeks (Lubis 2000). Plant maintenance had been done by watering using tap water every day. Visual symp- 
toms of Ganoderma attack and seedling growth, nutrient $\mathrm{N}$ content of plants and soil were observed at 8-month after planting.

Morphological observations of Azotobacter sp. was conducted using scanning electron microscopy (SEM). The experimental design used in this study was randomized block design to test the 7 treatments, namely inoculation of Azotobacter sp. + Ganoderma sp. (+A+G), Azotobacter sp. $+30 \% \mathrm{~N}$ fertilizer of recommended dosage + Ganoderma sp. $(+\mathrm{A}+30 \mathrm{~N}+\mathrm{G})$, Azotobacter sp. $+60 \% \mathrm{~N}$ fertilizer of recommended dosage + Ganoderma sp. $(+\mathrm{A}+60 \mathrm{~N}+\mathrm{G})$, Azotobacter sp. $+100 \% \mathrm{~N}$ fertilizer of recommended dosage + Ganoderma sp. $(+A+100 N+G)$, $100 \% \mathrm{~N}$ fertilizer of recommended dosage + Ganoderma sp. $(+100 \mathrm{~N}+\mathrm{G})$, Ganoderma sp. inoculation (positive control, $+G)$, and non-inoculated Ganoderma sp. (negative control, -G). The data obtained were tested by simple statistic and continued with Duncan Multiple Range Test (DMRT) with 5\% test.

\section{RESULT AND DISCUSSION}

Gram Characterization and Biochemical Properties of Azotobacter sp. Gram staining showed that Azotobacter sp. is Gram-negative bacteria and SEM observation had revealed that the isolate produced polysaccharides. Mandal et al. (2008) suggest this isolate is oval in shape that the formed polysaccharides are useful for protecting the activity of nitrogenase from reactive oxygenase, thereby increasing the activity of fixation. According to Samiran et al. (2012) exopolysacharida applications produced by Azotobacter sp. can be useful as growth promoting substances, increase plant resistance to drought stress, improve soil aggregates and increase soil microbial community interactions to inhibit pathogens. In addition, Azotobacter sp. also produce cyst at dormant stage. Based on the analysis reduction of acetylenic (ARA) activity of nitrogenase Azotobacter sp. used in this study was $0.727 \mu \mathrm{mol}$ hour- 1 .

\section{The Growth of Oil Palm Seedling}

The performance of oil palm seedlings growth after 8 months is presented in Figure 1 while the rooting of the plants is presented in Figure 2. The result of statistical analysis shows that the height of oil palm seedlings $+G$ lower than that of $-G$ although not significantly different (Table 1). The application of Azotobacter sp. in addition to $30 \% \mathrm{~N},+60 \% \mathrm{~N}$, and $+100 \% \mathrm{~N}$ significantly yield higher palm seedling growth compared to those $+G$, while $+A+G$ did not yield significantly higher growth compared to those $+G$. These results indicate that inoculation of

Table 1 Growth of oil palm seedling in each treatment tested

\begin{tabular}{lllllll}
\hline \multirow{2}{*}{ Treatment $^{*}$} & \multicolumn{2}{l}{$\begin{array}{l}\text { Seedling height } \\
(\mathrm{cm})\end{array}$} & Leaf number & \multicolumn{2}{c}{ Fresh weight $(\mathrm{g})$} & \multicolumn{2}{c}{ Dry weight $(\mathrm{g})$} \\
\cline { 4 - 7 } & $29.9 \mathrm{ab}$ & $5.3 \mathrm{a}$ & $113.0 \mathrm{ab}$ & $23.7 \mathrm{a}$ & $55.3 \mathrm{ab}$ & $8.4 \mathrm{a}$ \\
\hline $\mathrm{A}+\mathrm{G}$ & $34.9 \mathrm{c}$ & $5.6 \mathrm{a}$ & $81.3 \mathrm{ab}$ & $20.67 \mathrm{a}$ & $39.6 \mathrm{ab}$ & $6.6 \mathrm{a}$ \\
$\mathrm{A}+30 \mathrm{~N}+\mathrm{G}$ & $33.2 \mathrm{bc}$ & $6.2 \mathrm{a}$ & $67.7 \mathrm{ab}$ & $13.8 \mathrm{a}$ & $323 \mathrm{ab}$ & $4.6 \mathrm{a}$ \\
$\mathrm{A}+60 \mathrm{~N}+\mathrm{G}$ & $32.7 \mathrm{bc}$ & $5.5 \mathrm{a}$ & $132.7 \mathrm{~b}$ & $23.6 \mathrm{a}$ & $63.8 \mathrm{~b}$ & $6.6 \mathrm{a}$ \\
$\mathrm{A}+100 \mathrm{~N}+\mathrm{G}$ & $30.8 \mathrm{ab}$ & $6.3 \mathrm{a}$ & $57.7 \mathrm{a}$ & $13.6 \mathrm{a}$ & $24.8 \mathrm{a}$ & $6.8 \mathrm{a}$ \\
$100 \mathrm{~N}+\mathrm{G}$ & $28.1 \mathrm{a}$ & $5.8 \mathrm{a}$ & $65.0 \mathrm{a}$ & $197 \mathrm{a}$ & $29.4 \mathrm{a}$ & $7.9 \mathrm{a}$ \\
$\mathrm{G}$ & $31.5 \mathrm{abc}$ & $5.9 \mathrm{a}$ & $51.4 \mathrm{a}$ & $147 \mathrm{a}$ & $26.4 \mathrm{a}$ & $6.3 \mathrm{a}$ \\
\hline
\end{tabular}

*A: Azotobacter sp; G: Ganoderma sp.: 30N: 30\% recommended doseage of N; $60 \mathrm{~N}: 60 \%$ recommended doseage of $\mathrm{N}$ fertilizer; $100 \mathrm{~N}$ : $100 \%$ recommended doseage of $\mathrm{N}$ fertilizer. 


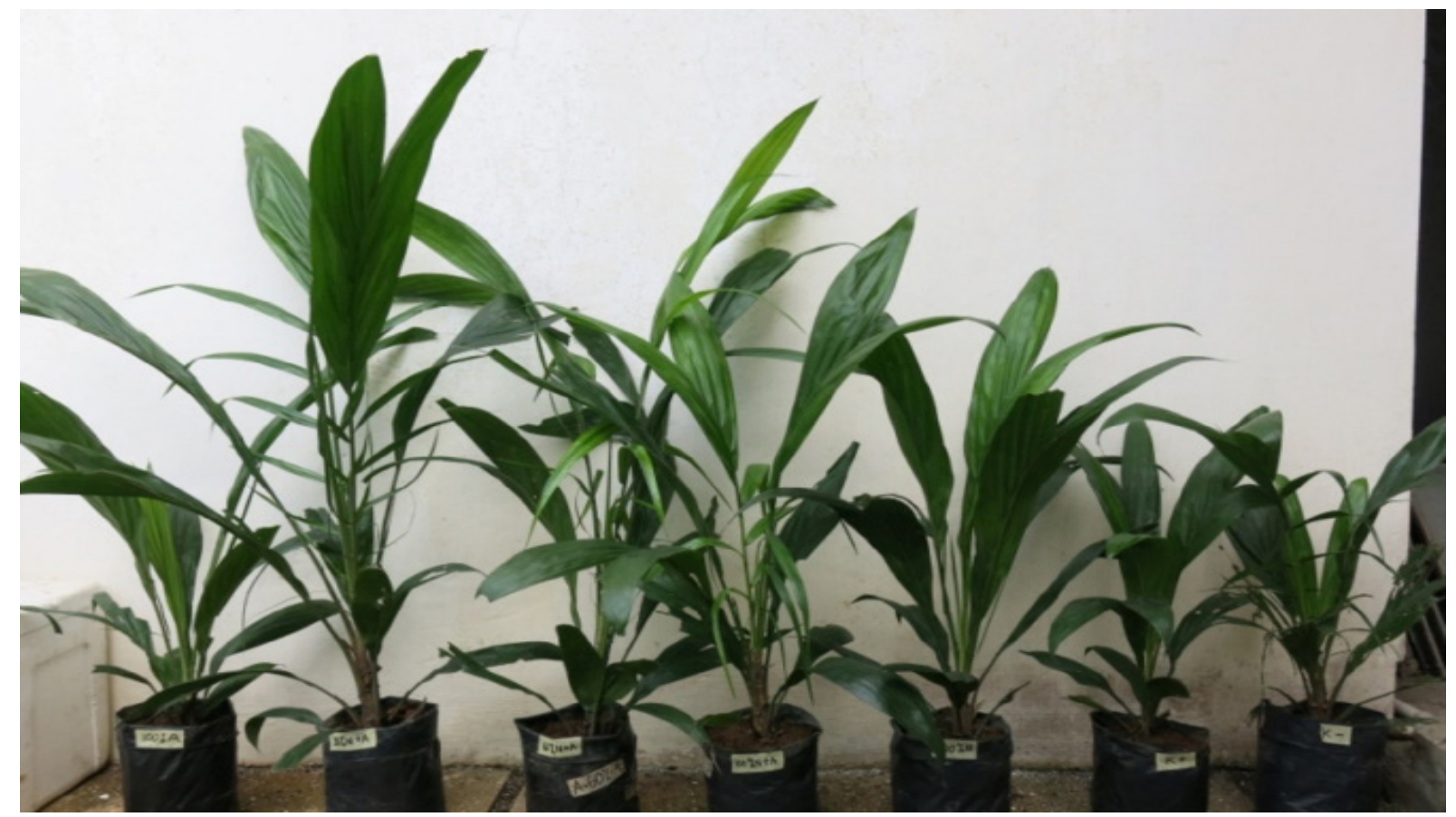

Figure 1 Oil palm seedling performance in each treatment. From left to right: Azotobacter sp. + Ganoderma sp. (+A+G), Azotobacter sp.+30\% N fertilizer of recommended dosage + Ganoderma sp. $(+\mathrm{A}+30 \mathrm{~N}+\mathrm{G})$, Azotobacter sp. $+60 \% \mathrm{~N}$ fertilizer of recommended dosage + Ganoderma sp. $(+A+60 N+G)$, Azotobacter sp. $+100 \% \mathrm{~N}$ fertilizer of recommended dosage. + Ganoderma sp. $(+A+100 N+G), 100 \% N$ fertilizer of recommended dosage + Ganoderma sp. $(+100 N+G)$, Ganoderma sp. inoculation (positive control, $+G$ ), and 7) non inoculated Ganoderma sp. (negative control, $-G)$.

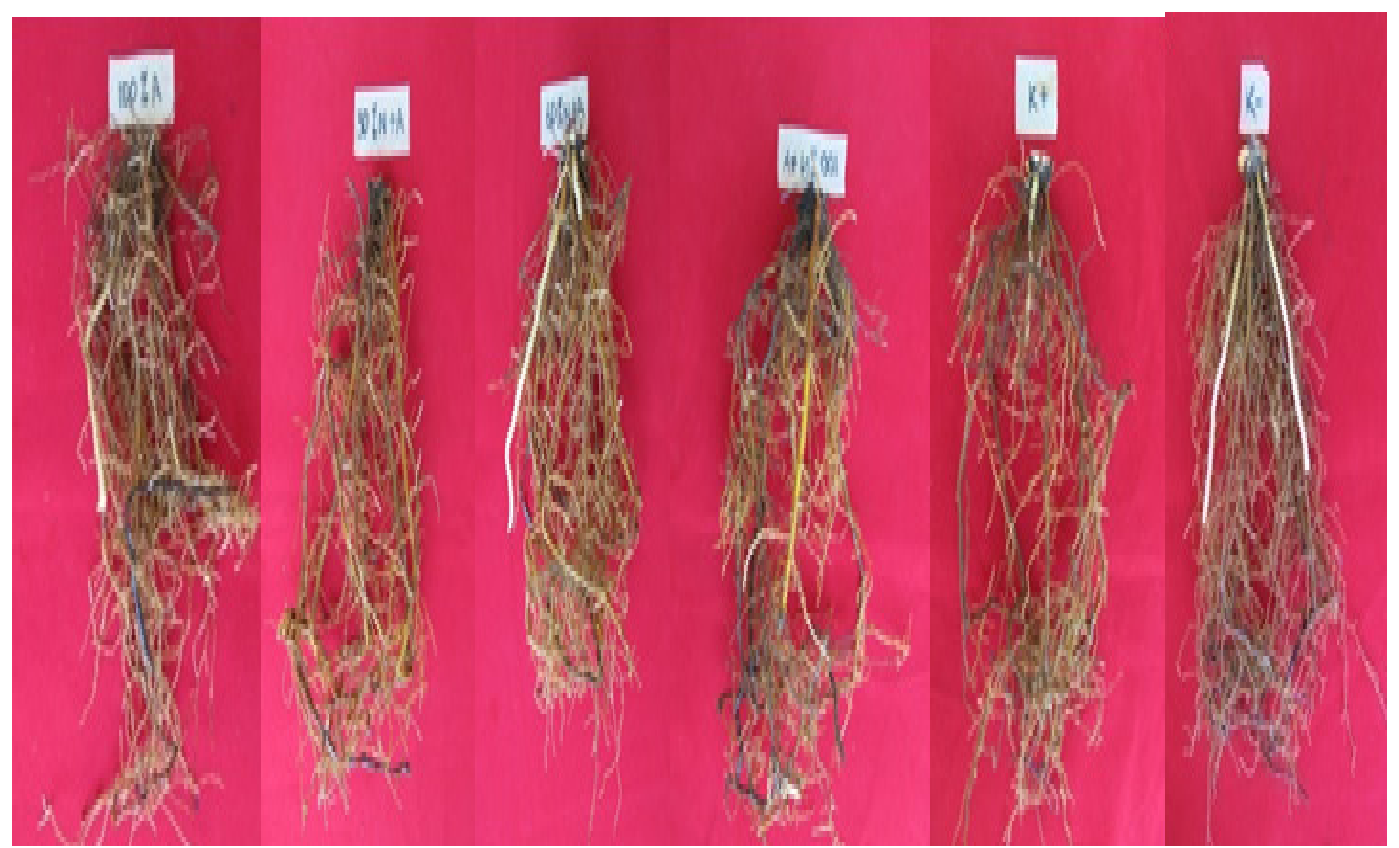

Figure 2 Oil palm root performance in each treatment. From left to right: Azotobacter sp. + Ganoderma sp. $(+A+G)$, Azotobacter sp. $+30 \% \mathrm{~N}$ fertilizer of recommended dosage + Ganoderma sp. $(+\mathrm{A}+30 \mathrm{~N}+\mathrm{G})$, Azotobacter sp. $+60 \% \mathrm{~N}$ fertilizer of recommended dosage + Ganoderma s. $(+\mathrm{A}+60 \mathrm{~N}+\mathrm{G})$, Azotobacter sp. $+100 \% \mathrm{~N}$ fertilizer of recommended dosage + Ganoderma sp. $(+A+100 N+G), 100 \% N$ fertilizer of recommended dosage + Ganoderma sp. $(+100 N+G)$, Ganoderma sp. inoculation (positive control, $+G$ ), and non inoculated Ganoderma sp. (negative control, $-\mathrm{G}$ ). 
Table 2 Nitrogen status of soil and leaf and Azotobacter population in soil

\begin{tabular}{llll}
\hline \multirow{2}{*}{ Treatment $^{*}$} & \multicolumn{2}{l}{$\begin{array}{l}\text { Population of } \\
\text { Azotobacter }\end{array}$} & \multicolumn{2}{l}{$\mathrm{N}$ concentration (\%) } \\
\cline { 3 - 4 } & $(\mathrm{cfu})$ & soil & leaf \\
\hline $\mathrm{A}+\mathrm{G}$ & $5.0 \times 10^{3}$ & $0.19 \mathrm{~b}$ & $2.09 \mathrm{a}$ \\
$\mathrm{A}+\mathrm{N} 30+\mathrm{G}$ & $2.0 \times 10^{2}$ & $0.21 \mathrm{bc}$ & $2.26 \mathrm{~b}$ \\
$\mathrm{~A}+\mathrm{N} 60+\mathrm{G}$ & $3.0 \times 10^{2}$ & $0.20 \mathrm{~b}$ & $2.61 \mathrm{bc}$ \\
$\mathrm{A}+\mathrm{N} 100+\mathrm{G}$ & $4.0 \times 10^{2}$ & $0.21 \mathrm{bc}$ & $2.64 \mathrm{bc}$ \\
$\mathrm{N} 100+\mathrm{G}$ & $1.0 \times 10^{2}$ & $0.27 \mathrm{c}$ & $2.98 \mathrm{c}$ \\
$\mathrm{G}$ & $2.9 \times 10^{3}$ & $0.23 \mathrm{bc}$ & $1.86 \mathrm{a}$ \\
$-\mathrm{G}$ & $3.2 \times 10^{2}$ & $0.12 \mathrm{a}$ & $1.82 \mathrm{a}$ \\
\hline
\end{tabular}

${ }^{\star}$ A: Azotobacter sp.; G: Ganoderma sp. N30: 30\% recommended doseage of $\mathrm{N}$; N60: $60 \%$ recommended doseage of $\mathrm{N}$ fertilizer; $\mathrm{N} 100: 100 \%$ recommended doseage of $\mathrm{N}$ fertilizer.

Ganoderma sp. slightly inhibited the growth ofseedling height and $\mathrm{N}$ nutrient adequacy did not seem to be fulfilled from the fixation of $\mathrm{N}$ Azotobacter sp. alone but should be combined with addition of $\mathrm{N}$ fertilizer. Better growth of plants inoculated with Azotobacter sp. and $\mathrm{N}$ fertilizer appears to be able to increase plant resistance to Ganoderma sp attack. In addition, Basidiomycetes among which Ganoderma sp. is within this Division, known as a major agent in the decomposition of cell wall polymers. Laboratory test results indicate that an increasing of inorganic $\mathrm{N}$ concentration can suppress the transcription of fungi genes necessary for lignin and lignocellulose metabolism (Li et al. 1994) and may even lead to a change in the composition of the fungi basidiomisetes (Edwards et al. 2011). These results indicate that $\mathrm{N}$ fertilization may inhibit Ganoderma sp. activity. Further Elsenlord et al. (2014) suggested that the presence of $\mathrm{N}$ in the soil significantly reduced the population and the diversity of genes involved in depolymerization of starch $(12 \%)$, hemicellulose $(16 \%)$, cellulose $(16 \%)$ and chitin $15 \%$ and $16 \%$ lignin which generally had an effect on weathering and accumulation of organic matter.
However, this possibility does not occur in the presence of $\mathrm{N}$ fixation due to fixation by Azotobacter which is different in addition to other functions of Azotobacter sp. Rasmussen et al. (2008) suggested that in Lolium perenne plants infected with endophytic nitric microbes showed a decrease in some amino and magnesium acids, while the water-soluble carbohydrate content, fats, some organic acids and chlorogenic acids, increased. On the other hand, the application of $\mathrm{N}$ fertilizer causes an increase in organic and lipid acids while water-soluble carbohydrates, kholorogenic acids, and fiber decreases. These results indicate thar there is differences in metabolism between $\mathrm{N}$ fertilized plants and infected endophytic fungi.

Widiastuti et al. (2013) showed that there was low correlation between population of Azotobacter sp. and the attack rate of Ganoderma sp. among the observed microbial parameters analyzed such as total microbes, total fungi, phosphate solubilizing bacteria and total cellulolytic fungi. In addition to $\mathrm{N}$ fixers Azotobacter sp. also produces indole acetic acid hormone known as plant growth promoting (Widiastuti et al. 2010). With the presence of Azotobactersp. the plant gets sufficiency supply of nitrogen and IAA that promote plants to survive Ganoderma sp. attacks. This can be seen in Table 1, the height of palm fertilized with N 100\% of recommended dosage was $30.75 \mathrm{~cm}$ while the treatment of $\mathrm{N}$ fertilizer at various doses combined with Azotobacter sp. causing an increase in plant height of 2-4 cm. The addition of $\mathrm{N} 100 \%$ fertilizer alone $(+\mathrm{N} 100+\mathrm{G})$ resulted in seedlings heights that are not significantly different from those given by Azotobacter sp. only $(+A+G)$. This result indicates that the supply of $\mathrm{N}$ from fixation by Azotobacter sp. had been sufficient to support the superior performance of oil palm seedlings. 
The seedlings of oil palm treated with $+\mathrm{A}+\mathrm{N} 30-100$ that are inoculated with Azotobacter $\mathrm{sp}$. accompanied by $\mathrm{N}$ fertilizer appears to show leaf breakage (Figure 1). These results are thought to be due to the precence of IAA hormone produced by Azotobacter sp. which is not found in the application of $\mathrm{N}$ fertilizer (urea) alone, especially at low doses of $\mathrm{N}$ fertilizer. Although, the number of leaves was not different in all treatments tested (Table 1), however, $+\mathrm{N} 100+\mathrm{G}$ gave the highest number of leaves, while $+A+G$ yielded the lowest number of leaves. The relatively short observation period may not be sufficient to show the effect of treatments to the number of leaves.

Treatment of $+\mathrm{A}+\mathrm{N} 30$ and $+\mathrm{A}+\mathrm{N} 60$, yielded fresh and dried shoot biomass unsignificantly different from those $+G$, but on the $+A+100 N+G$ resulting in fresh and dry biomass weight significantly higher than that $+\mathrm{G}$. Between $30 \%$ doses and $60 \%$ of $\mathrm{N}$ fertilizer there was no significant difference in fresh and shoot biomass weight compared to those $100 \mathrm{~N}$ dose. These results suggest that a higher dose of $\mathrm{N}$ may be required to produce fresh and dry weight of plant infected with Ganoderma sp.

The performance of oil palm seedlings is presented in Figure 2. In general, oil palm seedlings did not show symptoms of Ganoderma sp. Infection such as decay, however, inoculation of Ganoderma sp. reduced the development of rooting. Azotobacter inoculation alone results in better rooting but the best rooting treatment is $+\mathrm{A}+30 \mathrm{~N}+\mathrm{G}$ and $+\mathrm{A}+60 \mathrm{~N}+\mathrm{G}$. Addition of Azotobacter sp. does not significantly affect fresh and dry weight of roots biomass but there is a tendency that all Azotobacter sp. application results in higher fresh roots biomass compared to $+\mathrm{N} 100+\mathrm{G}$. These results indicate that the application of $\mathrm{N}$ fertilizer inhibits root growth. Application of Azotobacter sp. seems to promote root growth, thus decreasing the need of $\mathrm{N}$ fertilizer. The optimum $\mathrm{N}$ fertilizer is $60 \%$.

\section{Soil and Leaf nutrient Status as well as Azotobacter Populations in Rhizo- sphere of Oil Palm Seedlings}

Population of Azotobacter sp. in soil with the inoculation treatment of Ganoderma sp. was higher than without inoculation of Ganoderma sp. It is generally shown that Azotobacter sp. were found in all rhizosphere of oil palm seedlings, although the highest population was found in $+A+G$ treatment. The cause of high population in this treatment can not be explained using available data in this study.

The result of $\mathrm{N}$ soil analysis indicated that the soil $N$ content in $+G$ treatment is significantly higher than that of $-G$. The cause of this can not be explained in this study. The same results were found on soil in oil palm seedlings of $+A+30 N+G$, $+A+60 N+G$, and $+A+100 N+G$ compared to that $-\mathrm{G}$. However, the soil $\mathrm{N}$ content in these plant rhizosphere was not significantly different compared to those $+G$ treatment.

Decrease in dosage of $\mathrm{N}$ fertilizer up to $70 \%$ but accompanied by Azotobacter sp. application did not cause any significant difference to soil $\mathrm{N}$ levels. These results indicate that there is influence of Azotobacter sp. although this influence is not significant. Inoculation of Azotobacter $\mathrm{sp}$. seemed to cause an increase in soil $\mathrm{N}$ as a result of $\mathrm{N}_{2}$ fixation activity by $A z O-$ tobacter sp. However, it seems that $\mathrm{N}_{2}$ fixation activity did not give the same influence on soil $\mathrm{N}$ levels as that of $100 \% \mathrm{~N}$ fertilizer application.

The result of $\mathrm{N}$ leaf analysis showed that $\mathrm{N}$ content of leaf of oil palm seedlings $+G$ were not significantly different to $-G$. These results suggest that inoculation of Ganoderma sp. had no effect on leaf $\mathrm{N}$ content. However, $+\mathrm{A}+100 \mathrm{~N}+\mathrm{G}$, $+A+60 N+G$, and $+A+30 N$ yield signifi- 
cantly higher $\mathrm{N}$ leaf compared to that $-\mathrm{G}$. These results also show that a reduction in the dose of $\mathrm{N}$ fertilizer $40 \%$ accompanied by Azotobacter sp. $(+A+60 N+G)$ produce the same $\mathrm{N}$ leaf content with $+\mathrm{N} 100+\mathrm{G}$. It supposed that Azotobacter application increase the efficiency of $\mathrm{N}$ fertilizer application.

These results indicate that addition of Azotobacter sp. can improve the efficiency of $\mathrm{N}$ fertilizer but in high $\mathrm{N}$ addition the $\mathrm{N}$ leaf content does not significant difference. Azotocbacter is a free-living $\mathrm{N}$-fixing bacteria. The magnitude of $\mathrm{N}$ fixation capability is strongly influenced by micro-environments including soil $\mathrm{N}$ levels as well as root exudates produced by plants as a source of carbon and energy for the activity of fixation $\mathrm{N}$. The fixing ability of $\mathrm{N}_{2} A z O-$ tobacter sp. is $10 \mathrm{mg} \mathrm{N}_{2} \mathrm{~g}^{-1}$ carbohydrate (glucose). The main sources of carbon are sugars, alcohols, salts, and organic acids. This bacterium grows 48 hours at a temperature of $30^{\circ} \mathrm{C}, \mathrm{pH} 7-7.5$, with a smony colony, opaque, slightly convex (low convex), and viscid. Carvalho et al. (2014) suggests that these bacteria produce increased yield and growth because other functions besides their ability to fix $\mathrm{N}$ also produce IAA, gibberellin and cytokinin. In high $\mathrm{N}$ conditions, the activity of Azotocbacter sp. less optimum and even at high $\mathrm{N}$ the possibility of plants producing different root exudates and not supporting the development of Azotobacter sp. However, inoculation of Azotobacter $\mathrm{sp}$. still need $\mathrm{N}$ fertilizer application. The results of Kiba et al. (2011) suggests that there is interaction between nutrients $\mathrm{N}$ with phytohormon which ultimately affect the growth and development of plants. Both phytohormon and nitrogen simultaneously alter the physiology and morphology of plants. According to Adesemoye et al. (2008) Azotobacter sp. including in plant growth-promoting bacteria (PGPR) that can induce root hair growth and increase root surface area so that roots absorb more nutrients to meet the need of plants.

\section{CONCLUSION}

Addition of Azotobacter sp. affect the growth of oil palm seedlings inoculated by Ganoderma sp. Although shoot N content did not show any significant differences between plants with and without Azotobacter sp. but the treatment of $+\mathrm{A}+100 \mathrm{~N}+\mathrm{G}$ significantly increase fresh and dry weight biomass compared to those $+100 N+G$.

\section{REFERENCES}

Adesemoye AO, Torbert HA, Kloepper JW. 2008. Enhanced plant nutrient use efficiency with PGPR and AMF in an integrated nutrient management system. Can J Microbiol. 54:876-886.

Carvalho TLG, Balsemão PE, Saraiva RM, Ferreira PCG, Hemerly AS. 2014. Nitrogen signalling in plant interactions with associative and endophytic diazotrophic bacteria. J Exp Bot. 65(19):5631-5642.

Edwards IP, Zak DR, Kellner H, Eisenlord SD, Pregitoer KS. 2011. Simulated atmospheric $\mathrm{N}$ deposition alters fungal community composition and suppresses lignolytic gene expression in northern hardwood forest. PLOS one. (20421): DOI:10.13.1/journal. pone.0020421.

Elsenlord SZ, Freedman DRZ, He KZ, Zhon J. 2014. Microbial mechanisms mediating increased soil $C$ storage under elevated atmospheric $\mathrm{N}$ deposition. Appl Environ Microbiol. 79(4):1191-1199.

Jamieson MA, Seastedt TR, Bowers KD. 2012. Nitrogen enrichment differential- 
ly affects above-and belowground plant defense. Am J Bot. 99(10):1630-1637.

Kiba TTK, Kojima M, Sakakibara H. (2011). Hormonal control of nitrogen acquisition: role of auxin, abscisic acid, and cytokinin. J Exp Bot. 62(4):13991408.

Kloepper JW, Ryu CM, Zhang S. 2004. Induced systemic resistance and promotion of plant growth by Bacillus spp. Phytopathology. 94:1259-1266.

Lakshmanan, Selvaraj VG, Bais HP. 2013. Functional Soil Microbiome: Belowground Solutions to an Aboveground Problem. Plant Physiol. 166:689-700.

Li, Alic DM, Gold MH. 1994. Nitrogen regulation of lignin peroxidase gene transcription. Appl Environ Microbiol. 60:3447-3449.

Lubis AU. 2000. Kelapa Sawit Teknik Budidaya Tanaman Perkebunan. Medan (ID): Sinar Medan.

Mandal SM, Pati BR, Das AK, Ghosh AK. 2008. Characterization of asymbiotically effective Rhizobium resistant to arsenic: Isolated from the root nodules of Vigna mungo (L.) Hepper grown in anarsenic-contaminated field. J Gen Appl Microbiol. 54:93-99.

Nosheen A, Bano A, Ullah F. 2013. Bioinoculants: a sustainable approach to maximize the yield of Ethiopian mustard (Brassica carinata L.) under low input of chemical fertilizers. Tox Indus Health. Oct 2013.

Olese JE, Jorgensen LN, Peterson J, Mortensen JV. 2003. Effects of rate and timing of nitrogen fertilizer on disease control by fungicides in winter wheat. $\mathrm{J}$ Agric Sci. 140:1-13.

Rasmussen S, Parsons AJ, Fraser K, Xue $\mathrm{H}$, Newman JA. 2008. Metabolic profiles of Lolium perenne are differentially affected by nitrogen supplay, carbohydrate content, and fungal endophyte infection. Plant Physiol. 146:1440-1453.

Romero YS, Moreno, Guzman J, Espan G, Segura D. 2013. Sigma Factor RpoS Controls Alkylresorcinol Synthesis through ArpR, a LysR-Type Regulatory Protein, during Encystment of Azotobacter vinelandii. J Bacteriol. 195(8):1834-1844.

Samiran S, Gauri SM, Mandal BR, Pati. 2012. Impact of Azotobacter exopolysaccharides on sustainable agriculture. Appl Microbiol Biotechnol. 95:331-338. Widiastuti $\mathrm{H}$, Siswanto, Suharyanto. 2010. Karakterisasi dan seleksi beberapa isolat Azotobacter sp. untuk meningkatkan perkecambahan benih dan pertumbuhan tanaman. Bul Plasma Nutfah. 16(2):160-167.

Widiastuti H, Suharyanto, Novianti F, Wulaningtyas A, Trisning. 2011. Pengujian kefektifan teknik inokulasi Ganoderma sp. berdasarkan dot immunobinding assay (DIBA). J Penel Kelapa Sawit.18:72-82.

Widiastuti H, Suharyanto, Taniwiryono D, Susanto A. 2013. Microbial community in selected oil palm rhizospheres infected by Ganoderma sp. at different levels. PIPOC. 19-20 Nov. Malaysia. 